\title{
Protective and Treatment Effect of Germinated Turnip Seeds (Brassica Rapa L.) and Radish Seeds (Raphanus sativus L.) against Carbon Tetrachloride - Induced Hepatotoxicity in Rats
}

\author{
Elshahat G. El-Dreny
}

Special Food and Nutrition Dep., Food Tech. Res. Inst., Agric. Res. Center, Egypt Received: 10 Oct. 2019 / Accepted 15 Dec. $/ 2019$ Publication date: 30 Dec. 2019

\begin{abstract}
This study was carried out with the aim of studying the effect of germinated radish seeds and turnip seeds against carbon tetrachloride - induced hepatotoxicity in rats. The chemical composition of radish and turnip seeds before and after germinated. Total phenolics, total flavonoids, antioxidant activity and fatty acids have been studied in germinated radish and turnip seeds. A biological experiment was carried out on 30 male rats. Rats were divided into six groups (five in group) the experiment was 8 weeks. The first three groups are (preventive groups) are not injected with carbon tetrachloride, the first group $\mathrm{G}_{1}$ fed on basal diet only, the second group $\mathrm{G}_{2}$ fed on basal diet supplemented with $10 \%$ germinated radish seeds and the third group $\mathrm{G}_{3}$ fed on basal diet supplemented with $10 \%$ germinated turnip seeds. Other treated groups had hepatotoxicity with carbon tetrachloride the fourth group $\mathrm{G}_{4}$ fed on the basal diet only, the fifth group $\mathrm{G}_{5}$ fed on basal diet supplemented with $10 \%$ radish sprouts and the sixth group $\mathrm{G}_{6}$ rats fed on basal diet supplemented with $10 \%$ turnip sprouts. Results showed that the germinated seeds content high amount of protein and ash and a decrease in their content of fats compared to non-germinated seeds. Germinated seeds are rich in mineral elements, unsaturated fatty acids and antioxidants. Reduced serum lipid profile, improvement in liver and kidney functions in rats fed on germinated radish seeds and turnip seeds compared to rats fed on the basal diet only. Through the results of this study, the possibility of using germinated radish seeds and turnip seeds for the prevention and treatment of liver patients.
\end{abstract}

Keywords: Germinated radish, germinated turnip seeds, phenolics, flavonoids, antioxidant activity, kidney functions and liver functions.

\section{Introduction}

Liver is the biggest organ in the body safeguard the body by detoxification and organize normal physiological, it plays a main role in fat metabolism by bile acid excretion, it helps the fat soluble vitamin stockpiling and utilization and metabolism of drugs (Gao et al., 2008). Although the liver actively removes toxins from several the chemical compounds and drugs harm the liver through various mechanisms, these drugs and chemicals usually trigger biochemical pressure inside the hepatocytes by covalent attachment or by direct mitochondrial damage, usually this leads to a heavy load of oxidative stress despite modifying the stress that stimulates signal pathways and ultimately leads to diminishing mitochondrial function, according to the World Health Organization (WHO) about $75 \%$ of unique drug interactions lead to liver transplantation or death, it is one of the main reasons to withdraw various clinically used drugs from the market (Martin et al., 2000 ).

The role of carbon tetrachloride $\left(\mathrm{CCL}_{4}\right)$ in producing liver toxicity is imperative in animal protective models for the liver. It typically mimics the biochemical changes and cellular injury as other xenobiotics made in liver. This halogenated alkane explicates the mechanisms of action of hepatotoxic properties like fatty degeneration, hepatocellular death, fibrosis, and carcinogenicity (Weber et al., 2003). It is known that when taking $\mathrm{CCL}_{4}$, it will quickly be metabolized to $\mathrm{CCL}_{3}$ (trichloromethyl radical) due to activation of cytochrome enzymes in the liver. The formed free radicals can interact with glutathione and groups of protein and initiate lipid peroxide in hepatocytes, Hence $\mathrm{CCL}_{4}$ use in making liver injury is the best available method that can be used to find out the ability of herbal preparations to have antioxidant capacity (Nurrochmad et al., 2013).

Herbal medicine has been known to play an important role in treatment various diseases, including hepatopathy (Venukumar and Latha, 2002). Several traditional investigators have said that

Corresponding Author: Elshahat G. El-Dreny, Special Food and Nutrition Dep., Food Tech. Res. Inst., Agric. Res. Center. Egypt. E-mail: drelshahatgomaa12018@gmail.com 
various medicinal plants and their formulations can be used effectively to relieve various types of liver ailment (Dash et al., 2007).

Cruciferous sprouts are distinctive functional foods for the reason that of their rich in composition bioactive compounds compared to other plants. Germinated seeds may contain more than twice as various phytochemicals depending on varieties, species, and environmental conditions (Baenasa et al., 2017).

Germination resulted in a significant increase in the phytonutrient and micronutrient content of all the selected seeds, which proves that there is a noticeable increase in the nutritional value of the seeds on sprouting. This ultimately indicates that sprouts should be considered a vital component of the diet and can be combined to improve agricultural productivity and their use easily by low income families (Wagner et al., 2013).

Germinated radish seeds belongs to cruciferous family. Radish seeds has been cultivated for thousands of years in both the Mediterranean region and China. In general radish seeds comprises carbohydrates, ether extract, dietary fiber and crude protein. Germinated radish seeds found to contain unique biologically active compounds that have health benefits for humans (Aly, 2015). Numerous studies have proven that herbs and plant products have an effective role in protecting the liver, due to their antioxidant properties as a source of ascorbic acid and a sulfur-containing compound, radish seeds can compete with free radicals in cell components and protect the liver from infection (Naghibi et al., 2003). Research recently stated that methanol extract from germinated radish seeds had higher activity than L-ascorbic acid in protecting the liver because it was rich in antioxidants like flavonoids and sinapinic acid esters and was responsible for this activity (Takaya et al., 2003).

Turnip seed is a potential functional food for liver health and it is rich in sinapine thiocyanate (ST), it is one of the active constituents in liver protection, and is responsible, at least in part, for the hepatic influence of turnip seed, which also means that some cruciferous plants rich in sinapine thiocyanate can also It is useful for the liver functions (Rao et al., 2016).

The present work is planned to determine the chemical constituents of germinated radish seeds and turnip seeds qualitatively and assess their effects against acute hepatotoxicity induced by $\mathrm{CCl}_{4}$ in rats.

\section{Materials and Methods}

\section{Materials}

Radish seeds and turnip seeds were obtained from the local market of Kafr ElSheikh City, Egypt, other materials carbon tetrachloride $\left(\mathrm{CCL}_{4}\right)$, paraffin oil, vitamins, casein, cellulose, minerals and Kits for serum blood examination were purchased from El- Gomhoria Company for chemicals and drugs, Cairo, Egypt.

\subsection{Germination seeds}

Radish and turnip seed to cleaning and not including broken seeds and soaking in water by placing $20 \mathrm{~g}$ of radish and turnip seeds in a glass pot containing $200 \mathrm{ml}$ of tap water and soaking for 12 $\mathrm{h}$ at room temperature after that has been removed the water then the seeds have been washed every 8 $\mathrm{h}$ for 5 days at the end of germination period, the germinated seeds were washed and sun-air dried for 3 days before crumpled into powder the method according to Tork, (2017).

\section{Methods}

\subsection{Proximate analysis}

Crude protein, ether extract, fiber and ash were determined according to AOAC (2012), total carbohydrates was determined by difference.

\subsection{Determination of total phenolic content}

Total phenolic content of germinated radish and turnip seeds were assayed as described by Meda et al., (2005).

\subsection{Determination of total flavonoids content}

Total flavonoids content of germinated radish and turnip seeds were determined by a spectrophotometric method described by Boateng et al., (2008). 


\subsection{Determination of DPPH radical-scavenging activity}

DPPH radical-scavenging activity were determined agreeing to procedure outlined by Moure et al., (2001).

\subsection{Fatty acids analysis}

Fatty acids composition in germinated radish and turnip seeds were determined according to the procedure described by ISO (2015).

\subsection{Experimental animals and diet}

Thirty adult male albino rats weighting between $(240 \mathrm{~g}-220 \mathrm{~g})$ were obtained from experimental animal house of Food Technology Research Institute, Agric, Res., Center, Giza, Egypt. The animals were kept under observation in a well-ventilated cage under day light and hygienic condition for ten days before experiment and fed on standard diet and water ad libitum. The basal diet supplies of protein, fat, carbohydrates, vitamins and minerals was in accordance with the recommended dietary allowances for rats (Reeves et al.,1993), basal diet was comprised of $20 \%$ protein (casein), $10 \%$ sucrose, $5 \%$ corn oil, $2 \%$ choline chloride, $1 \%$ vitamins mixture, $3.5 \%$ salt mixture and $5 \%$ fibers (cellulose) and the remainder was corn starch up to $100 \%$.

\subsection{Experimental design}

The experiment was performed in Animal House in Food Technology. Research Institute, Agric, Res., Center, Giza, Egypt. After the adaptation period 30 rats divided into two main groups, the first group ( $\mathrm{n}=15$ rats) divided three group was not injected with $\mathrm{CCL}_{4}$, negative control $\left(\mathrm{G}_{1}\right)$ rats fed on the basal diet only, $\mathrm{G}_{2}$ rats fed on the basal diet containing with $10 \%$ of germinated radish seeds powder, $\mathrm{G}_{3}$ rats fed on the basal diet containing with $10 \%$ of germinated turnip seeds powder. The rats of second group main ( $\mathrm{n}=15$ rats) were subcutaneously injected by $2 \mathrm{ml} / \mathrm{kg}$ of weight rat of $\mathrm{CCL}_{4}$ diluted with liquid paraffin (1:1 v: v) weekly during experiment period to induce hepatotoxicity according to (Li et al., 2013). The rats of second group main divided to three group positive control (G4) rats fed on the basal diet, $\mathrm{G}_{5}$ rats fed on the basal diet containing with $10 \%$ of germinated radish seeds powder, $\mathrm{G}_{6}$ rats fed on basal diet containing with $10 \% \mathrm{~g} / \mathrm{kg}$ of turnip sprouts powder.

Group (1): normal rats feed on basal diet control negative (-ve) group.

Group (2): rats feed on basal diet containing $10 \%$ germinated radish seeds

Group (3): rats feed on basal diet containing $10 \%$ germinated turnip seeds

Group (4): hepatotoxicity rats kept a positive control (+ ve) group and fed on basal diet.

Group (5): Injected rats with by $\mathrm{CCL}_{4}$ were fed on basal diet containing $10 \%$ germinated radish seeds Group (5): Injected rats with by $\mathrm{CCL}_{4}$ were fed on basal diet containing $10 \%$ germinated turnip seeds

At the end of experiment ( 8 weeks) each animal was anaesthetized with ethyl ether. The blood collects from vein plexus eye and put in dry clean centrifuged for $10 \mathrm{~min}$ at $3000 \mathrm{rpm}$ to separate the serum, which was kept frozen at $-20^{\circ} \mathrm{C}$ in clean dry plastic until analyzed.

\subsection{Biochemical Analyses:}

Serum aspartate aminotransferase(AST) and alanine aminotransferase(ALT) (Bergmeyer, et al., 1978) and alkaline phosphatase(ALP) (Roy ,1970), total cholesterol (TC) (Allain, et al., 1974), triglycerides(TG) (Buccolo and David, 1973) and high density lipoprotein cholesterol(HDL-C) (Lopes-virella et al., 1977), were chemically determined using specific kits. Low density lipoprotein cholesterol (LDL-C) was calculated using the formula of (Friedewald et al.,1972). Urea and serum total protein (TP) was chemically determined (Okokon et al., 2013) and Serum albumin (Alb) according to the procedure of (Fernandez et al., 1966). Serum total bilirubin (TBil) was estimated (Stiehl, 1982). Uric acid and creatinine were determined according to the method described by (Trinder, 1969) and (Jaffẻ, 1986).

\section{Statistical analysis:}

Results were expressed as the mean \pm SD. Data for multiple variable comparisons were analyzed by one-way analysis of variance (ANOVA). For the comparison of significance between 
groups, Duncan's test was used as a post hoc test according to the statistical package program (Armitage and Berry, 1987).

\section{Results}

1. Proximate analysis of germinated radish and turnip seeds and non-germinated seeds powder:

The proximate analysis of germinated radish and turnip seeds and non-germinated seeds were studied in Table 1. The results indicated that the content of germinated radish and turnip seeds for crude protein and ash, increases markedly in comparison to non-germinated seeds on dry weight basis, the increase crude protein content in germinated seeds might be due to reduction of seed nitrates such as lipids into plant protein (metabolic enzymes), and also loss in dry weight through respiration during germination. The results showed a decrease in the fat content in radishes and turnip sprouts compared to non-germinated seeds. Also may be due to the using of lipid to produce energy which necessitated for protein biosynthesis process. Therefore, it is recommended to eat these germinated in diets for weight loss as reported by (Abdallah, 2008). The content of germinated seeds of total carbohydrates and fibers was increased compared to non-germinated seeds. The results agree with (Islam et al., 2019) reported that chemical composition of radish seed content $22.40 \%$ protein, $3.66 \%$ ash, $38.69 \%$ ether extract, $18.68 \%$ crude fiber and $30.15 \%$ total carbohydrates. Germinated radish seeds $35.80 \%$ protein, $9.38 \%$ ash, $8.69 \%$ total lipid $14.68 \%$ crude fiber and $45.26 \%$ total carbohydrates.

Table 1: Effect of germination process on chemical composition of radish and Turnip seeds (on dry weight basis).

\begin{tabular}{|c|c|c|c|c|}
\hline Samples & $\begin{array}{c}\text { Radish } \\
\text { seed }\end{array}$ & $\begin{array}{c}\text { Germinated radish } \\
\text { seeds }\end{array}$ & $\begin{array}{c}\text { Turnip } \\
\text { seed }\end{array}$ & $\begin{array}{c}\text { Germinated turnip } \\
\text { seeds }\end{array}$ \\
\hline Protein (\%) & 23.68 & 29.58 & 20.57 & 27.34 \\
\hline Fat $(\%)$ & 33.77 & 09.43 & 40.35 & 02.99 \\
\hline $\operatorname{Ash}(\%)$ & 04.33 & 10.64 & 03.94 & 09.34 \\
\hline Crude fiber (\%) & 14.35 & 18.57 & 20.56 & 25.87 \\
\hline Total Carbohydrates (\%) & 38.22 & 50.35 & 35.14 & 60.33 \\
\hline
\end{tabular}

\section{Total phenol compound, flavonoids and antioxidant activity in germinated radish and turnip} seeds.

The results in Table 2 explained that the total phenolic contents of germinated radish and turnip seeds were contained $819 \mathrm{mg} / 100 \mathrm{~g}$ and $601 \mathrm{mg} / 100 \mathrm{~g}$, respectively. Also germinated radish seeds and germinated turnip seeds contents of flavonoids $193 \mathrm{mg} / 100 \mathrm{~g}$ and $245 \mathrm{mg} / 100 \mathrm{~g}$ respectively. The results also show that the antioxidant activity of germinated radish and turnip seeds is very high. The results agree with (Paulina et al., 2014) indicated that germinated radish seeds higher total phenolic(TP), total flavonoid (TF) and antioxidant activity content in compared to non-germinated radish seeds, germinated radish seeds significantly increases the levels of phenolic acids and flavonoids, as well as their antioxidant activity.

Table 2: Total phenol compound, flavonoids and antioxidant activity in germinated radish and turnip seeds.

\begin{tabular}{lccc}
\hline \multirow{2}{*}{ Sample } & \multicolumn{2}{c}{$\mathbf{( m g / 1 0 0 g )}$} & \\
\cline { 2 - 4 } & $\begin{array}{c}\text { Total phenolics } \\
\text { as gallic acid }\end{array}$ & $\begin{array}{c}\text { Flavonoids } \\
\text { as catechin }\end{array}$ & DPPH \\
\hline Radish germinated & 819 & 193 & $89.92 \%$ \\
Turnip germinated & 601 & 245 & $86.85 \% \%$ \\
\hline
\end{tabular}

Therefore, germinated edible seeds are a very valuable source of natural antioxidants and sprouts could be used as ingredients in functional foods. Pasko et al., (2009) also reported that higher total phenolic content in germinated seeds compared with non-germinated seeds, suggesting that synthesis of phenolic antioxidants during germination may occur, it is thought that seeds mainly act as a reservoir for the development of the sprouts. 
3. Fatty acids composition of germinated radish and turnip seeds powder.

Fatty acids composition of germinated radish and turnip seeds were given in Table 3 . The results showed that erucic acid, oleic acid, linoleic acid, linolenic acid and eicosenoic acid are the main and the major unsaturated fatty acids in both radish and turnip seeds sprouts. It could be observed that germinated radish seeds and germinated turnip seeds sprouts have higher amount of total unsaturated fatty acids were $(89.2 \%)$ and $(93.24 \%)$ respectively. These results agree with (Islam et al., 2019) who indicated that major fatty acids for germinated radish seeds were oleic acid, linoleic acid, linolenic acid, and erucic acid.

Table 3: Fatty acids content of germinated radish and turnip seeds powder (mg/100g oil).

\begin{tabular}{lccc}
\hline Fatty acids & Symbol & $\begin{array}{c}\text { Germinated radish } \\
\text { seeds }\end{array}$ & $\begin{array}{c}\text { Germinated turnip } \\
\text { seeds }\end{array}$ \\
\hline Myristic acid & $\mathrm{C} 14: 0$ & 0.09 & $\mathrm{ND}$ \\
Palmitic acid & $\mathrm{C} 16: 0$ & 5.37 & 2.21 \\
Palmitoleic acid & $\mathrm{C} 16: 1$ & 0.16 & 0.13 \\
Margaric acid & $\mathrm{C} 17: 0$ & 0.04 & 0.02 \\
Heptadecanoic acid & $\mathrm{C} 17: 1$ & 0.05 & 0.10 \\
Stearic & $\mathrm{C} 18: 0$ & 1.73 & 0.95 \\
Oleic acid & $\mathrm{C} 18: 1$ & 16.31 & 10.74 \\
Linoleic acid(Omega6) & $\mathrm{C} 18: 2$ & 11.94 & 15.01 \\
Linolenic acid(Omega3) & $\mathrm{C} 18: 3$ & 8.37 & 7.43 \\
Arachidic acid & $\mathrm{C} 20: 0$ & 1.32 & 0.82 \\
Eicosenoic acid & $\mathrm{C} 20: 1$ & 8.77 & 7.74 \\
Behenic acid & $\mathrm{C} 22: 0$ & 1.72 & 0.93 \\
Erucic acid & $\mathrm{C} 22: 1$ & 43.6 & 52.09 \\
Total saturated fatty acid & SAF & 10.27 & 4.93 \\
Total Unsaturated fatty acid & USFA & 89.2 & 93.24 \\
& Unknown & 0.53 & 1.83 \\
\hline
\end{tabular}

4. Effect of germinated radish seeds and germinated turnip seeds sprouts powder on plasma lipid parameters in rats.

Table 4. Shows plasma lipid profiles (TC, TG, LDL-C, v LDL-C, and HDL-C, in the normal and hepatic rats fed germinated radish seeds and germinated turnip seeds powder. The results showed that the level of(TC, TG, LDL-C and v LDL-C in the rats fed $10 \%$ germinated radish and $10 \%$ germinated turnip powder was lower compared with control group (negative control and positive control), but the HDL-C were higher compared with control groups. These results agree with Aly et al., (2015) who indicated that the diabetic rats fed on Egyptian radish sprouts (ERS) had favorably modified serum lipid profile in rats with decrease in total cholesterol (TC), triglyceride (TG), vLDLC, LDL-C and increase high density lipoprotein cholesterol.

\section{Effect of feeding germinated radish and turnip seeds powder on liver parameters in rats.}

Acute intoxication of rats by $\mathrm{CCL}_{4}$ induced significant increases in serum levels of liver enzymes aspartate aminotransferase (AST), alanine aminotransferase (ALT), alkaline phosphatase (ALP) and bilirubin compared to the negative control group. The results presented in Table 5. Showed that rats fed germinated radish and turnip seeds powder reduced AST, ALT, ALP and bilirubin levels compared to positive and negative control, which shows that radish and turnip sprouts have an effective role in improving liver function. These results agree with Ali, (2015) who indicated that the pre-treatment of rats with Brassica rapa juice protected the rats against $\mathrm{CCL}_{4}$-induced hepatotoxicity, the treatment significantly reduced the GOT, GPT, alkaline phosphatase (ALP) and bilirubin level. In addition, these results agree with Aly et al., (2015) showed that the treatment with radish sprout improved the liver and kidney functions. 
Table 4: Effect of germinated radish and turnip seeds powder on plasma lipid parameters in rats.

\begin{tabular}{|c|c|c|c|c|c|}
\hline Groups & $\begin{array}{c}\text { TC } \\
(\mathrm{mg} / \mathrm{dl})\end{array}$ & TG (mg/dl) & $\begin{array}{l}\text { LDL-C } \\
\text { (mg/dl) }\end{array}$ & $\begin{array}{c}\text { v LDL-C } \\
(\mathrm{mg} / \mathrm{dl})\end{array}$ & $\begin{array}{r}\text { HDL-C } \\
\text { (mg/dl) }\end{array}$ \\
\hline \multicolumn{6}{|l|}{ Protective group } \\
\hline $\mathbf{G}_{1}-$ Control (-ve) & $\begin{array}{l}98.00^{\mathrm{d}} \\
\pm 1.45\end{array}$ & $\begin{array}{c}110.00^{\mathrm{c}} \\
\pm 3.58\end{array}$ & $\begin{array}{l}29.00^{\mathrm{d}} \\
\pm 1.13\end{array}$ & $\begin{array}{l}22.00^{c} \\
\pm 1.14\end{array}$ & $\begin{array}{l}47.00^{\mathrm{a}} \\
\pm 1.33\end{array}$ \\
\hline G2- $_{2}$ Radish germinated & $\begin{array}{c}94.33^{\text {de }} \\
\pm 0.58\end{array}$ & $\begin{array}{c}103.33^{\mathrm{c}} \\
\pm 2.89\end{array}$ & $\begin{array}{l}25.43^{\mathrm{e}} \\
\pm 0.56\end{array}$ & $\begin{array}{l}20.67^{c} \\
\pm 0.58\end{array}$ & $\begin{array}{l}48.34^{\mathrm{a}} \\
\pm 0.58\end{array}$ \\
\hline$G_{3}-$ Turnip germinated & $\begin{array}{c}95.67^{\mathrm{de}} \\
\pm 1.58 \\
\end{array}$ & $\begin{array}{c}108.32^{\mathrm{c}} \\
\pm 3.68 \\
\end{array}$ & $\begin{array}{c}25.66^{\mathrm{e}} \\
\pm 0.58 \\
\end{array}$ & $\begin{array}{l}21.66^{\mathrm{c}} \\
\pm 1.53 \\
\end{array}$ & $\begin{array}{l}48.33^{\mathrm{a}} \\
\pm 0.54 \\
\end{array}$ \\
\hline \multicolumn{6}{|l|}{ Treated group } \\
\hline $\mathbf{G}_{4}-\operatorname{Control}(+\mathbf{v e})$ & $\begin{array}{c}170.76^{\mathrm{a}} \\
\pm 2.08\end{array}$ & $\begin{array}{c}176.00^{\mathrm{a}} \\
\pm 1.73\end{array}$ & $\begin{array}{l}95.66^{\mathrm{a}} \\
\pm 1.15\end{array}$ & $\begin{array}{l}35.34^{\mathrm{a}} \\
\pm 0.58\end{array}$ & $\begin{array}{l}39.67^{\mathrm{c}} \\
\pm 1.15\end{array}$ \\
\hline $\mathbf{G}_{5}-\mathrm{CCL}_{4}+$ Radish germinated & $\begin{array}{c}140.33^{\mathrm{c}} \\
\pm 2.51\end{array}$ & $\begin{array}{c}146,67^{\mathrm{b}} \\
\pm 2.88\end{array}$ & $\begin{array}{l}68.00^{c} \\
\pm 1.00\end{array}$ & $\begin{array}{l}29.32^{\mathrm{b}} \\
\pm 0.57\end{array}$ & $\begin{array}{l}43.00^{\mathrm{b}} \\
\pm 1.00\end{array}$ \\
\hline $\mathrm{G}_{5}-\mathrm{CCL}_{4}+$ Turnip germinated & $\begin{array}{c}145.67^{\mathrm{b}} \\
\pm 1.53\end{array}$ & $\begin{array}{c}153.33^{\mathrm{b}} \\
\pm 1.87\end{array}$ & $\begin{array}{l}73.43^{\mathrm{b}} \\
\pm 0.58\end{array}$ & $\begin{array}{c}30.66^{\mathrm{b}} \\
\pm 0.58\end{array}$ & $\begin{array}{l}41.66^{\mathrm{b}} \\
\pm 0.58\end{array}$ \\
\hline
\end{tabular}

* Each value was an average of five determinations \pm standard deviation

* Values followed by the same letter in columns are not significantly different at LSD at $\mathrm{p} \leq 0.05$

Table 5: Effect of feeding germinated radish and turnip seeds powder on liver functions in rats.

\begin{tabular}{lcccc}
\hline Groups & $\begin{array}{c}\text { ALT } \\
\text { (U/L) }\end{array}$ & $\begin{array}{c}\text { AST } \\
\text { (U/L) }\end{array}$ & $\begin{array}{c}\text { ALP } \\
\text { (U/L) }\end{array}$ & $\begin{array}{c}\text { Bilirubin } \\
\text { (mg/dl) }\end{array}$ \\
\hline Protective groups & & & & \\
G1- Control (-ve) & $34.00^{\mathrm{d}}$ & $35.67^{\mathrm{c}}$ & $72.67^{\mathrm{d}}$ & $0.275^{\mathrm{c}}$ \\
& \pm 1.00 & \pm 0.58 & \pm 2.08 & \pm 1.73 \\
G2- Radish germinated & $33.00^{\mathrm{d}}$ & $34.34^{\mathrm{c}}$ & $71.33^{\mathrm{d}}$ & $0.265^{\mathrm{c}}$ \\
& \pm 1.00 & \pm 0.57 & \pm 2.08 & \pm 1.57 \\
G3-Turnip germinated & $33.33^{\mathrm{d}}$ & $35.00^{\mathrm{c}}$ & $72.00^{\mathrm{d}}$ & $0.270^{\mathrm{c}}$ \\
\hline Treated group & \pm 1.53 & \pm 1.00 & \pm 2.00 & \pm 2.53 \\
G4-Control (+ve) & & & & \\
& $63.34^{\mathrm{a}}$ & $85.00^{\mathrm{a}}$ & $115.33^{\mathrm{a}}$ & $0.653^{\mathrm{a}}$ \\
G5-CCL4+Radish germinated & \pm 1.53 & \pm 2.00 & \pm 0.54 & \pm 1.53 \\
& $50.00^{\mathrm{c}}$ & $70.68^{\mathrm{b}}$ & $93.69^{\mathrm{c}}$ & $0.408^{\mathrm{b}}$ \\
G6-CCL4+Turnip germinated & \pm 2.00 & \pm 1.53 & \pm 1.15 & \pm 1.43 \\
& $53.67^{\mathrm{b}}$ & $72.34^{\mathrm{b}}$ & $101.33^{\mathrm{b}}$ & $0.384^{\mathrm{b}}$ \\
\hline
\end{tabular}

*Each value was an average of five determinations \pm standard deviation

*Values followed by the same letter in columns are not significantly different at LSD at $\mathrm{p} \leq 0.05$

\section{Effect of feeding radish and turnip sprouts powder on kidney function in rats.}

Table 6 showed that acute intoxication of rats by $\mathrm{CCl}_{4}$ induced significant increases in serum levels of urea, uric acid and creatinine. Meanwhile, a decrease in total protein and albumin. The results showed that decrease levels of urea, uric acid and creatinine and increases in total protein and albumin in the groups feeding on germinated radish and turnip seeds compared to the positive and negative control. From these results we conclude that germinated radish and turnip seeds play an effective role in improving kidney function. These results agree with Aly et al., (2015) explained that the treatment with sprout improved the liver and kidney functions.

\section{Effect of germinated radish and turnip seeds powder on relative weight of different organs in} rats.

Table 7 showed that there was no significant difference in relative weight of spleen between the different treatment groups compared to control group. On the other hand, the results showed that decrease in the kidney and liver weight in the groups feeding on germinated radish seeds and germinated turnip seeds compared to the control group. 
Table 6: Effect of germinated radish and turnip seeds powder on serum Total protein, Albumin, Globulin, Urea, Creatinine and Uric acid in rats

\begin{tabular}{|c|c|c|c|c|c|}
\hline Groups & $\begin{array}{c}\text { Total protein } \\
\text { mg/dl }\end{array}$ & $\begin{array}{c}\text { Albumin } \\
\text { mg /dl }\end{array}$ & $\begin{array}{c}\text { Urea } \\
\mathrm{mg} / \mathrm{dl}\end{array}$ & $\begin{array}{c}\text { Creatinine } \\
\text { mg/dl }\end{array}$ & $\begin{array}{c}\text { Uric acid } \\
\mathrm{mg} / \mathrm{dl}\end{array}$ \\
\hline \multicolumn{6}{|l|}{ Protective groups } \\
\hline $\mathbf{G}_{1}$ - Control (-ve) & $\begin{array}{l}7.63^{\mathrm{a}} \\
\pm 0.15\end{array}$ & $\begin{array}{l}3.30^{\mathrm{a}} \\
\pm 0.58\end{array}$ & $\begin{array}{l}57.00^{\mathrm{b}} \\
\pm 2.08\end{array}$ & $\begin{array}{l}0.698^{\mathrm{a}} \\
\pm 1.24\end{array}$ & $\begin{array}{r}4.73^{\mathrm{a}} \\
\pm 1.27\end{array}$ \\
\hline 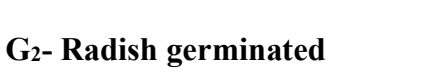 & $\begin{array}{l}7.87^{\mathrm{a}} \\
\pm 0.06\end{array}$ & $\begin{array}{l}3.50^{\mathrm{a}} \\
\pm 2.53\end{array}$ & $\begin{array}{l}53.00^{\mathrm{c}} \\
\pm 1.00\end{array}$ & $\begin{array}{l}0.679^{\mathrm{a}} \\
\pm 1.63\end{array}$ & $\begin{array}{r}4.63^{\mathrm{a}} \\
\pm 1.25\end{array}$ \\
\hline 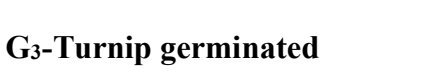 & $\begin{array}{r}7.77^{\mathrm{a}} \\
\pm 1.53\end{array}$ & $\begin{array}{l}3.37^{\mathrm{a}} \\
\pm 1.53\end{array}$ & $\begin{array}{c}55.00^{\mathrm{bc}} \\
\pm 1.00\end{array}$ & $\begin{array}{l}0.692^{\mathrm{a}} \\
\pm 1.45\end{array}$ & $\begin{array}{l}4.70^{\mathrm{a}} \\
\pm 2.27\end{array}$ \\
\hline \multicolumn{6}{|l|}{ Treatment groups } \\
\hline $\mathbf{G}_{4}-$ Control $(+v e)$ & $\begin{array}{l}3.77^{\mathrm{d}} \\
\pm 0.12\end{array}$ & $\begin{array}{l}1.65^{\mathrm{c}} \\
\pm 1.63\end{array}$ & $\begin{array}{l}68.67^{\mathrm{a}} \\
\pm 1.52\end{array}$ & $\begin{array}{l}0.815^{\mathrm{c}} \\
\pm 0.53\end{array}$ & $\begin{array}{c}6.12^{\mathrm{c}} \\
\pm 2.53\end{array}$ \\
\hline $\mathbf{G}_{5}-\mathrm{CCL}_{4}+\mathrm{Radish}_{\text {germinated }}$ & $\begin{array}{l}5.86^{\mathrm{b}} \\
\pm 1.24\end{array}$ & $\begin{array}{l}2.74^{\mathrm{b}} \\
\pm 3.55\end{array}$ & $\begin{array}{c}57.33^{\mathrm{bc}} \\
\pm 2.53\end{array}$ & $\begin{array}{l}0.723^{\mathrm{b}} \\
\pm 2.53\end{array}$ & $\begin{array}{l}5.31^{\mathrm{b}} \\
\pm 3.15\end{array}$ \\
\hline $\mathrm{G}_{6}-\mathrm{CCL}_{4}+$ Turnip germinated & $\begin{array}{l}5.27^{\mathrm{c}} \\
\pm 1.43\end{array}$ & $\begin{array}{l}2.38^{\mathrm{b}} \\
\pm 1.93\end{array}$ & $\begin{array}{l}58.34^{\mathrm{b}} \\
\pm 2.54\end{array}$ & $\begin{array}{c}0.786^{\text {bc }} \\
\pm 1.23\end{array}$ & $\begin{array}{l}5.85^{\mathrm{b}} \\
\pm 1.00\end{array}$ \\
\hline
\end{tabular}

* Each value was an average of five determinations \pm standard deviation

* Values followed by the same letter in columns are not significantly different at LSD at $\mathrm{p} \leq 0.05$

Table 7: Effect of radish and turnip germinated powder on relative weight of different organs in rats.

\begin{tabular}{|c|c|c|c|}
\hline Groups & $\begin{array}{l}\text { Relative weight } \\
\text { of Liver } \\
\text { (g) }\end{array}$ & $\begin{array}{c}\text { Relative weight of } \\
\text { Kidney } \\
\text { (g) }\end{array}$ & $\begin{array}{c}\text { Relative weight } \\
\text { of Spleen } \\
\text { (g) }\end{array}$ \\
\hline \multicolumn{4}{|l|}{ Protective groups } \\
\hline $\mathbf{G}_{1}$ - Control (-ve) & $\begin{array}{l}3.08^{\mathrm{b}} \\
\pm 0.16\end{array}$ & $\begin{array}{l}0.71^{\mathrm{b}} \\
\pm 0.15\end{array}$ & $\begin{array}{l}0.53^{\mathrm{a}} \\
\pm 0.22\end{array}$ \\
\hline $\mathbf{G}_{2}-10 \%$ Radish germinated & $\begin{array}{l}2.90^{\mathrm{b}} \\
\pm 0.47\end{array}$ & $\begin{array}{c}0.69^{\mathrm{b}} \\
\pm 0.05\end{array}$ & $\begin{array}{l}0.47^{\mathrm{a}} \\
\pm 0.05\end{array}$ \\
\hline$G_{3}-10 \%$ Turnip germinated & $\begin{array}{l}3.03^{\mathrm{b}} \\
\pm 0.26\end{array}$ & $\begin{array}{l}0.68^{\mathrm{b}} \\
\pm 0.04\end{array}$ & $\begin{array}{l}0.49^{\mathrm{a}} \\
\pm 0.06\end{array}$ \\
\hline \multicolumn{4}{|l|}{ Treatment groups } \\
\hline $\mathbf{G}_{4}-\mathbf{C o n t r o l}(+\mathbf{v e})$ & $\begin{array}{l}3.73^{\mathrm{a}} \\
\pm 0.44\end{array}$ & $\begin{array}{l}0.94^{\mathrm{a}} \\
\pm 0.17\end{array}$ & $\begin{array}{l}0.63^{\mathrm{a}} \\
\pm 0.06\end{array}$ \\
\hline G5-CCL4+Radish germinated & $\begin{array}{l}3.17^{\mathrm{ab}} \\
\pm 0.39\end{array}$ & $\begin{array}{l}0.61^{\mathrm{b}} \\
\pm 0.14\end{array}$ & $\begin{array}{r}0.46^{\mathrm{a}} \\
\pm 0.33\end{array}$ \\
\hline G6-CCL4+Turnip germinated & $\begin{array}{l}3.14^{\mathrm{ab}} \\
\pm 0.16\end{array}$ & $\begin{array}{r}0.65^{\mathrm{b}} \\
\pm 0.15\end{array}$ & $\begin{array}{l}0.46^{\mathrm{a}} \\
\pm 0.16\end{array}$ \\
\hline
\end{tabular}

* Each value was an average of five determinations \pm standard deviation

* Values followed by the same letter in columns are not significantly different at LSD at $\mathrm{p} \leq 0.05$.

\section{Discussion}

Innovative products must have added value, such as food for wellness. New uses of nutrients and bioactive components will drive emerging food technologies (Ubbink and Mezzenga, 2006). Cruciferous sprouts contain non-nutrient/health-promoting compounds, like diverse types of glucosinolates and phenolic compounds (Baenas et al., 2017).The biological activity developed by these compounds is mainly due to their antioxidant capacity, which could lower the deleterious consequences of excessively high levels of Reactive oxygen species (ROS) in cells, thus, decrease oxidative stress (OS) by providing cells with molecular tools to combat the imbalance between the production of ROS and the capacity to modulate the redox balance. These properties have direct effects on a number of cellular processes triggered by ROS, which are related to inflammation and oxidative reactions on DNA, proteins, and cell lipids (Gagné, 2014). In addition, to provide further molecular tools to cells to lower oxidative stress, many bioactive phytochemicals present in edible sprouts display biological functions that are crucial for the prevention of carcinogenesis processes and other chronic diseases (Gan et al., 2017).

The cruciferous seeds are an important source of riboflavin, thiamine, dietary fiber, and macro and micro elements. It represents a new type of ready-to-eat vegetable intended for direct 
consumption in fresh form and can also be used as ingredients in human diets. Currently, nutritionists have recommended the general consumption of various whole grains, vegetables and fruits, including germination or fermentation products (Henryk et al., 2005).

Methanol extracts of radish sprouts (Raphanus sativus L.) exhibited high antioxidant activity as the result of several kinds of sinapinic acid esters and flavonoids isolated with high radical scavenging potency, that contribute substantially to the biological activity (Takaya et al., 2003). The dichloromethane $\left(\mathrm{CH}_{2} \mathrm{Cl}_{2}\right)$ fraction, of the methanolic extract of radish sprouts, showed the highest induction potency for nicotinamide adenine dinucleotide (phosphate) $\mathrm{NAD}(\mathrm{P}) /$ quinone reductase $(\mathrm{QR})$, which plays critical roles in protection against chemical carcinogens and other toxic xenobiotics in hepatic cells. These results indicate that radish sprouts can be regarded as a safe and promising new dietary source for decreasing the risk of developing cancer and liver diseases (Lee and Lee, 2005).

Studies have shown that cruciferous family seeds (small radish, radish, white mustard and turnip seed) and 4-day-old sprouts have also been shown to contain inositol hex phosphate (IP- 6, phytic acid, or phytate when in its salt form). Moreover, this compound has been proved to be a biologically-active component, with potential health benefits -lowering blood glucose, reducing cholesterol and triacylglycerol, and decreasing the risk of cancer and heart disease (Frias et al.,2005).

Sinapic acid is a small naturally occurring hydroxyl cinnamic acid derivative. It is a phenolic compound and a member of the phenyl proponed family, the member of which are assumed as therapeutically beneficial and generally not toxic. Sinapic acid is widespread in the plant kingdom (fruits, vegetables, cereal grains, oilseed crops, and some spices and medicinal plants) and is common in human diet. Derivatives of sinapic acid are characteristic compounds of the Brassicaceae family. Sinapic acid shows antioxidant, antimicrobial, anti-inflammatory, anticancer, and anxiolytic activity. Mainly due to their antioxidant activity, these compounds have been suggested for potential use in food processing, cosmetics, and the pharmaceutical industry (Chen, 2016).

The hepatoprotective effects of sinapic acid in rats with carbon tetrachloride $\left(\mathrm{CCL}_{4}\right)$ induced acute hepatic injury was assessed. Sinapic acid treatment reduced $\mathrm{CCL}_{4}$-induced abnormalities in the histology of liver, liver malondialdehyde levels, serum aspartate transaminase and alanine transaminase activities. In addition, the treatment of sinapic acid significantly reduced the incidence of hepatitis (Shin et al., 2013).

\section{Conclusion}

In conclusion, the current results revealed that the oxidative damage caused by free radicals in the liver of rat due to $\mathrm{CCl}_{4}$ injection can be weakened through nutritional supplements of germinated radish seeds and germinated turnip seeds where this study demonstrated that these sprouts are rich in antioxidants that have an effect on improving liver and kidney functions and reduce lipid profile.

\section{References}

Abdallah, M.M.F., 2008. Seed sprouts, a pharaohs heritage to improve food quality. Arab University Journal of Agriculture Sci., 16: 469-478.

Ali E. Al-Snafi, 2015. The pharmacological importance of Brassica nigra and Brassica rapa grown in Iraq. Journal of Pharmaceutical Biology, 5(4): 240-253.

Allain, C.C., L.S. Poon, C.S.G. Chan, W. Richmond and P.C. Fu, 1978. Enzymatic determination of total serum cholesterol. Clin. Chem, 20: 470-475.

Aly, A.A., Tahany, S. A. Fayed, Amal M. Ahmed and E.A. El Rahim, 2015. Effect of Egyptian Radish and Clover Sprouts on Blood Sugar and Lipid Metabolisms in Diabetic Rats. Global Journal of Biotechnology \& Biochemistry, 10 (1): 16-21.

Aly, A.A.T., 2015. Biochemical studies of antidiabtiec effect of some seed sprouts in adult male albino rats. Ph.D. Thesis Dept. of Biochemistry, Fac. Of Agric. Cairo Univ.169.

AOAC, 2012. Official Methods of Analysis of Official Analytical Chemists $19^{\text {th }}$ Ed. Chapter, 4: 9-56.

Artimage, G.Y., and W.G. Berry, 1987. Statistical Methods $7^{\text {th }}$ Ed. Ames, Iowa Food Chem Toxicol, 52: 69-75.

Baenasa, N., I. Gómez-Jodarb, D.A. Morenoa, C. García-Vigueraa and P.M. Periago, 2017. Broccoli and radish sprouts are safe and rich in bioactive phytochemicals Nieves Baenasa. Postharvest Biology and Technology, 127:60-67. 
Bergmeyer, H.U., P. Schreiber and A.W. Wahlefeld, 1978. Optimization of methods for aspartate and alanine aminotransferase. Clin. Chem., 24: 58-61.

Boateng, J., M. Verghese, L. T. Walker and S. Ogutu, 2008. Effect of processing on antioxidant content in selected dry beans (Phaseolus spp. L.). LWT Food Science and Technology, 41: $1541-1547$.

Buccolo, G. and H. David, 1973. Quantitative determination of serum triglycerides by use of enzymes. Clin. Chem, 19: 476-482.

Chen, C., 2016. Sinapic Acid and Its Derivatives as Medicine in Oxidative Stress- Induced Diseases and Aging, Oxide Med Cell Longev, 3571614.

Dash, D.K., V.C. Yeligar, S.S. Nayak, T. Ghosh, D. Rajalingam, P. Sengupta, B.C. Maiti and T.K. Maty, 2007. Evaluation of hepatoprotective and antioxidant activity of Ichnocarpusfrutescens (Linn.) R.Br. on paracetamol- induced hepatotoxicity in rats. Trop J. Pharm. Res., 6(3): 755765.

Fernandez, A., C. Sobel and H. Goldenberg, 1966. An improved method for determination of serum albumin and globulin. Clin. Chem., 12(4): 194-205.

Frias, J., H. Zielinski, M.K. Piskula, H. Kozlowska, and C. Vival-Valverde, 2005. Inositol phosphate content and trypsin inhibitor activity in ready-to-eat cruciferous sprouts. Food Chemistry, 93: 331-336.

Friedewald, W.T., R.I. Levy and D.S. Frederickson, 1972. Estimation of plasma low density lipoprotein cholesterol concentration without use of the preparative ultracentrifuge. Clin. Chem, 18: 499-502.

Gagné, F., 2014. Chapter 6-Oxidative Stress. In Biochemical Ecotoxicology; Ed.; Academic Press: Oxford, UK, 103-115.

Gan, R.Y., W.Y. Lui, K. Wu, C.L. Chan, S.H. Dai, Z.Q. Sui and H. Corke, 2017 .Bioactive compounds and bioactivities of germinated edible seeds sprouts: An updated review. Trends Food Sci. Techno, 59:1-14.

Gao, B., W.I. Jeong, and Z. Tian, 2008. Liver: an organ with predominant innate immunity. Hepatology, 47(2): 729-736.

Henryk, Z., F. Juani, K. P. Mariusz, K. Halina and V. Concepcion, 2005. Vitamin B1 and B2, dietary fiber and minerals content of Cruciferae sprouts Eur Food Res Techno, 221:78-83.

Islam, M. T., A.A.M. Abdel Hafez, Fatma, A.A. Mostafa and M. Abdallah 2019.Influence of sprouting using biotic and abiotic elicitors on chemical composition of radish seeds (Raphanus sativus) AUJAS, Ain Shams Univ., Cairo, Egypt, Special Issue, 27(1): 717 - 726.

ISO12966-4:2015. International Organization for standardization, Animal and vegetable fats and oils, Gas chromatography of fatty acid methyl esters.

Jaffẻ, M., 1986. Determination of creatinine kineticin serum, plasma or urine. Zischer physiol \& Chem., 10: 391.

Lee, S.O., and I.S. Lee, 2006. Induction of quinone reductase, the phase 2 ant carcinogenic marker enzyme, cells by radish sprouts, Raphanus sativus L. Journal of Food Sciences, 71: 144-148.

Li, R., L. Xu, T. Liang, Y. Li, S. Zhang and X. Duan, 2013. Puerarin mediates hepatoprotection against $\mathrm{CCL}_{4}$-induced hepatic fibrosis rats through attenuation of inflammation response and amelioration of metabolic function. State University Press, 39-63.

Lopes-virella, M.E., P. Stone and S. Elliss, 1977. Cholesterol determination in high density lipoproteins eparated by three different methods. Clin Chem., 23: 876- 882.

Martin, M., M. Macias, G. Escames, R. Reiter, M. Agapito, G. Ortiz, and D. Castroviejo, 2000. Melatonin induced increased activity of the respiratory chain complexes I and IV can prevent mitochondrial damage induced by ruthenium red in vivo. Journal of Pineal Research, 28(4): 242-248.

Meda, A., C.E. Lamien, M. Romito, J. Millogo and O.G. Nacoulma, 2005. Determination of the total phenolic, flavonoid and proline contents in Burkina Fasan honey, as well as their radical scavenging activity. Food Chemistry, 91:571-577.

Moure, A., D. Franco, J. Sineiro, H. Dominguez, M.J. Nunez and J. M. Lema, 2001. Antioxidant activity of extracts from Gevuina avellana and Rosa rubiginosa defatted seeds. Food Research International, 34: 103-109. 
Naghibi, F., S. Pourmorad, and M. Shamsi, 2003. Decontamination of water with phenol using Raphanus sativus root. Iran. J. Pharm. Res., 2: 29-32.

Nurrochmad, A., S.A. Margono, A.R. Hakim, E. Kurniawati and E. Fatmawati, 2013.Hepatoprotective and antioxidant activity of pentagamavunon- 0 against carbon tetrachloride-induced hepatic injury in rats. Asian Pacific journal of tropical medicine, 6(6): 438-442.

Okokon, J.E., P.A. Nwafor, U. Charles, A. Dar and M.I. Choudhary, 2013. Antioxidative and hepatoprotective effects of ethanol root extract of Hippocratea africana against paracetamolinduced liver injury. Pharm. Biol., 51(7): 872-880.

Pasko, P., H. Barton, P. Zagrodzki, S., Gorinstein, M. Fołta and Z. Zachwieja, 2009. Anthocyanin, total polyphenols and antioxidant activity in amaranth and quinoa seeds and sprouts during their growth. Food Chemistry, 115, 994-998.

Paulina, P., S. Robert, G. Dorota, R. Jacek and F. Teresa, 2014. Phenolic profile and antioxidant activity in selected seeds and sprouts, Food Chemistry, 143:300-306.

Rao, F., Z. Yuting, G. Yiran, P. Tong and C. Fang, 2016. Hepatoprotection using Brassica rapa var. rapa $\mathrm{L}$. seeds and its bioactive compound, sinapine thiocyanate, for CCl4-induced liver injury Journal of Functional Foods, 22:73-81.

Reeves, P.G., F.H. Nielson and G.C. Fahmy, 1993. Reports of the American Institute of Nutrition, Adhoc Willing Committee on Reformulation of the AIN 93, Rodent diet. J. Nutr., 123: 19391951.

Roy, S.E., 1970. Colorimetric determination of serum alkaline phosphatase. Clin. Chem, 16: 431432.

Shin, D.S., K.W. Kim, H.Y., Chung, S. Yoon and J.O. Moon, 2013. Effect of sinapic acid against carbon tetrachloride-induced acute hepatic injury in rats, Arch Pharm Res, 36 (5): 626- 633.

Stiehl, A., 1982. Hyper bilirubinemia in liver disease. Fortschritte Medicine., 100(18): 842-845.

Takaya, Y., Y. Kondo, T. Furukawa and M. Niwa, 2003. Antioxidant constituents of radish sprout (Kaiware-daikon), Raphanus sativus L. J Agric Food Chem, 51:8061-8066.

Tork, M. Eman. 2017. Radish seed sprouting using saline water and their biochemical and pathological effects on albino rats. M.Sc. Thesis, Fac. Agric., Ain Shams Univ., 1-91.

Trinder, P., 1969. Colorimetric methods for determining uric acid in serum Plasma and urine. Ann. Clin. Biochem., 6: 24.

Ubbink, J. and Mezzenga, R. 2006. Delivery of functionality in complex food systems: introduction. Trends in Food Science and Technology, 17: 194-195.

Venukumar, M.R., and M.S. Latha, 2002. Hepatoprotective effect of the methanolic extract of Curculigoorchioidesin CCl4- treated rats. Indian J. Pharmacol, 34: 269- 275.

Wagner, A.E., A.M. Terschluesen and G. Rimbach, 2013. Health promoting effects of Brassicaderived phytochemicals from chemopreventive and anti-inflammatory activities to epigenetic regulation. Oxide. Med. Cell Longev. Article ID 964539, 12 p.

Weber, L.W., M. Boll and A. Stampfl, 2003. Hepatotoxicity and mechanism of action of haloalkanes: carbon tetrachloride as a toxicological model. Critical reviews in toxicology, 33(2): 105-136. 